\title{
Competition for food between the Mediterranean shag, the great cormorant and artisanal fisheries: a case study
}

\author{
Felipe Aguado-Giménez ${ }^{1}$, Sergio Eguía-Martínez ${ }^{2}$, Irene Torres-Campos ${ }^{1}$, \\ Santiago Meroño-García ${ }^{1}$, Jacinto Martínez-Ródenas ${ }^{3}$ \\ ${ }^{1}$ Instituto Murciano de Investigación y Desarrollo Agrario y Alimentario (IMIDA), Puerto de San Pedro del Pinatar, \\ 30740 Murcia, Spain. \\ (FA-G) (Corresponding author) E-mail: felipe.aguado@ carm.es. ORCID iD: http://orcid.org/0000-0001-8931-6180 \\ (IT-C) E-mail: irene.torres.c@gmail.com. ORCID iD: http://orcid.org/0000-0002-7753-0590 \\ (SM-G) E-mail: santi.merono@ gmail.com. ORCID iD: http://orcid.org/0000-0002-1195-2432 \\ ${ }^{2}$ MENDIJOB S.L., C/. Rambla 22, El Palmar, 30120 Murcia, Spain. \\ (SE-M) E-mail: sergio.eguia.martinez@gmail.com. ORCID iD: http://orcid.org/0000-0003-3606-4949 \\ ${ }^{3}$ Calle Secano 6B. Rincón de Seca, 30108, Murcia, Spain. \\ (JM-R) E-mail: jacinpajaro@ hotmail.com. ORCID iD: http://orcid.org/0000-0002-5469-7021
}

\begin{abstract}
Summary: The Mediterranean shag (Phalacrocorax aristotelis desmarestii) and the great cormorant ( $P$. carbo sinensis) are syntopic birds in an area encompassing Grosa Island and the Mar Menor coastal lagoon (SE Spain, western Mediterranean) during the breeding season of the former and the wintering period of the latter. Diet composition of both birds was studied through pellet analysis and otolith identification. Competition for fish resources between these two seabirds and with local artisanal fisheries was assessed. Shags preyed preferentially on small pelagic fish, and great cormorants mainly consumed demersal fish. Shag diet consisted of marine fish strictly, but great cormorant fed in all the available environments in the study area, including marine, transitional (coastal lagoon) and freshwater reservoirs. The great dissimilarity observed between shag and great cormorant diet composition showed no competition between them. The low shag population density and fishing effort in their foraging area suggested no competition with fisheries. Conversely, great cormorant population density in the study area was very high, and they foraged on fish of high commercial value. However, competition between great cormorant and artisanal fisheries only affected some of the less abundant species fished.
\end{abstract}

Keywords: competition; fisheries; great cormorant; otolith; predation; shag; syntopy.

Competencia por el alimento entre el cormorán moñudo, el cormorán grande y la pesca artesanal: un caso de estudio

Resumen: El cormorán moñudo (Phalacrocorax aristotelis desmarestii) y el cormorán grande ( $P$. carbo sinensis) son especies sintópicas en el entorno de Isla Grosa y la laguna costera del Mar Menor (SE de España, Mediterráneo occidental) durante la época de reproducción del primero que coincide con la invernada del segundo. Se estudia la composición de la dieta de ambas especies mediante la identificación de otolitos en sus egagrópilas, y se evalúa la competencia entre ambas especies y con la pesca artesanal local. El cormorán moñudo se alimentó mayoritariamente de pequeños peces pelágicos, y el cormorán grande consumió principalmente peces demersales. La dieta del cormorán moñudo consistió estrictamente de peces marinos, mientras que el cormorán grande capturó peces en los diferentes ambientes acuáticos de la zona de estudio, incluyendo especies marinas, de lagunas costeras e incluso de embalses de agua dulce. La gran disimilitud observada entre la composición de la dieta de ambas aves nos indica que no existe competencia por el alimento entre ellas. Asimismo, la baja densidad poblacional de cormorán moñudo y su esfuerzo pesquero en la zona de estudio tampoco demuestran competencia con la pesca artesanal local. Por el contrario, la abundancia de cormorán grande en la zona de estudio es muy alta, y se alimentaron principalmente de especies de alto valor comercial para los pescadores locales. No obstante, solo se observó competencia con la pesca artesanal local por alguna especie de pez de las menos abundantemente capturadas por los pescadores.

Palabras clave: competencia; pesquerías; cormorán grande; depredación; cormorán moñudo; sintopía.

Citation/Como citar este artículo: Aguado-Giménez F., Eguía-Martínez S., Torres-Campos I., Meroño-García S., Martínez-Ródenas J. 2018. Competition for food between the Mediterranean shag, the great cormorant and artisanal fisheries: a case study. Sci. Mar. 82(1): 7-15. https://doi.org/10.3989/scimar.04680.04B

Editor: D. Oro.

Received: June 20, 2017. Accepted: November 14, 2017. Published: December 18. 2017.

Copyright: (C) 2018 CSIC. This is an open-access article distributed under the terms of the Creative Commons Attribution 4.0 International (CC BY 4.0) License. 


\section{INTRODUCTION}

Conflicts between cormorant species and fishery activities are a worldwide concern (Carss et al. 1997). The interactions are site-specific, ranging from serious damage in breeding and wintering areas where commercial and recreational fisheries take place to unusually high or uncommon effects (Carss 1993, 2002, Lilliendahl and Solmundsson 2006). In some places on the Mediterranean coast, the European shag Phalacrocorax aristotelis spp. desmarestii (hereafter referred as the shag) and the great cormorant $P$. carbo spp. sinensis (hereafter referred as the cormorant) coexist during the breeding season of the former and the wintering period of the latter, i.e. they are syntopic species. One of these places is in Murcia (SE Spain; Fig. 1): Grosa Island holds a local shag breeding population of 12 to 18 pairs (Eguía-Martínez et al. 2015), and together with Redonda islet inside the nearby Mar Menor coastal lagoon, it also holds a wintering population of cormorant of about 5000 individuals (Molina 2013). During the breeding season, shag foraging areas are located near nesting colonies (Aguado-Giménez, pers. obs.), just as occurs around most breeding grounds (Wanless et al. 1991a). Conversely, cormorant mobility for feeding is greater during wintering, including both coastal and inland areas (Farinós and Robledano 2010). Although both bird species are opportunistic piscivorous predators (Carss 2002, Morat et al. 2014), we do not expect competition between them during syntopy, in line with the findings of Lilliendahl and Solmundsson (2006). Nevertheless, the large difference in their population sizes could suggest some interaction. Also, foraging of both species could increase pressure on prey populations (Lilliendahl and Solmundsson 2006), also interacting with the local artisanal fisheries occurring near the breeding-wintering area. Local fishermen are concerned with the increasing abundance of cormorants, though this interaction has not yet been evaluated.

Dietary studies of birds include regurgitated pellet analyses to characterize diet composition and estimate food intake through fish otolith identification (Hillersøy and Lorentsen 2012, Morat et al. 2014). Pellet collection is fairly easy, involving little or no disturbance to birds and analysis requires minimal laboratory facilities (Carss et al. 1997). Inferring diet composition after analysing regurgitated pellets is recognized as an appropriate proxy method for studying the diet of cormorant species (Duffy and Laurenson 1983, Barrett et al. 1990). In this work, we aimed to study the diet of syntopic shags and cormorants in the vicinity of Grosa Island and the Mar Menor coastal lagoon to determine whether there is potential competition with artisanal fishery and to check for any competition for food resources between the two bird species. To this end, freshly regurgitated pellets and fish otolith identification were used to explore shag and cormorant diet qualitatively and quantitatively. However, since there are criteria for (Johansen et al. 2001) and against (Carss et al. 1997) the utilization of pellets to infer total intake, the results obtained should be considered as a proxy.

\section{MATERIALS AND METHODS}

\section{The birds}

Shags and cormorants are very similar in appearance but each species has particular behavioural and morphological differentiating characteristics. From the point of view of foraging and potential competition, it is worth highlighting some of them. Both species are piscivorous but shags are almost exclusively marine birds that rarely penetrate estuaries or rivers (Harrison 2003). On the other hand, cormorants forage in a very wide range of aquatic environments, including both salt and fresh waters (Cramp and Simmons 1977). Both species are colonial waterbirds, breeding and roosting in groups. However, shags forage alone or in small groups of 2-4 individuals, whereas cormorants normally hunt in flocks, harassing the fish shoals against the shore and catching them in shallow waters (Van Eerden and Voslamber 1995). Nevertheless, cormorants also often forage alone. Cormorants are heavier (1.7 to $3.5 \mathrm{~kg}$ body mass) than shags (1.5 to $1.9 \mathrm{~kg}$ body mass) (Cramp and Simmons 1977, Fonteneau et al. 2009, Barros et al. 2013). Consequently, shags have lower daily energy requirements than cormorants (Ridgway 2010). Bill size also differs between the two species, culmen length being slightly shorter and bill depth considerably less deep in shags than in cormorants (Martínez-Abraín et al. 2006, Fonteneau et al. 2009, Barros et al. 2013).

\section{Study area}

The shag breeding colony is located on Grosa Island, and the cormorant roosting places on both Grosa Island and Redonda Islet (Murcia, SE Spain; Fig. 1; $\left.37^{\circ} 46^{\prime} 00^{\prime \prime} \mathrm{N}, 0^{\circ} 50^{\prime} 00^{\prime \prime} \mathrm{W}\right)$. Grosa Island and Redonda Islet are about $7.5 \mathrm{~km}$ apart. Also, there are two clearly differentiated roosting places at Grosa Island, one of them used by wintering cormorants and the other by post-breeding shags. Grosa Island is surrounded by one of the most extensive Posidonia oceanica meadows of the Mediterranean (Ruiz et al. 2015), interspersed with sandy patches and rocky reefs, and wide shallow sandy bottoms (MAPAMA 2017). As mentioned above, during the breeding season shags spend most of the time foraging next to the colony. Silty-sandy bottoms with low-density Cymodocea nodosa seagrasses dominate the nearshore seabed of the Mar Menor. At depths greater than $-3 \mathrm{~m}$, the sea floor becomes muddy and covered by a dense Caulerpa prolifera and $C$. nodosa mixed meadow (MAPAMA 2017). Cormorants often hunt in the shallowest zones of the Mar Menor, and their foraging area overlaps with the main fishing grounds in the Mar Menor.

\section{Pellet sampling}

In Grosa Island, shag pellets were collected early in the morning from nest platforms during the 2016 breeding season, in mid-February. To minimize disturbance to shags, pellets were collected during a single 


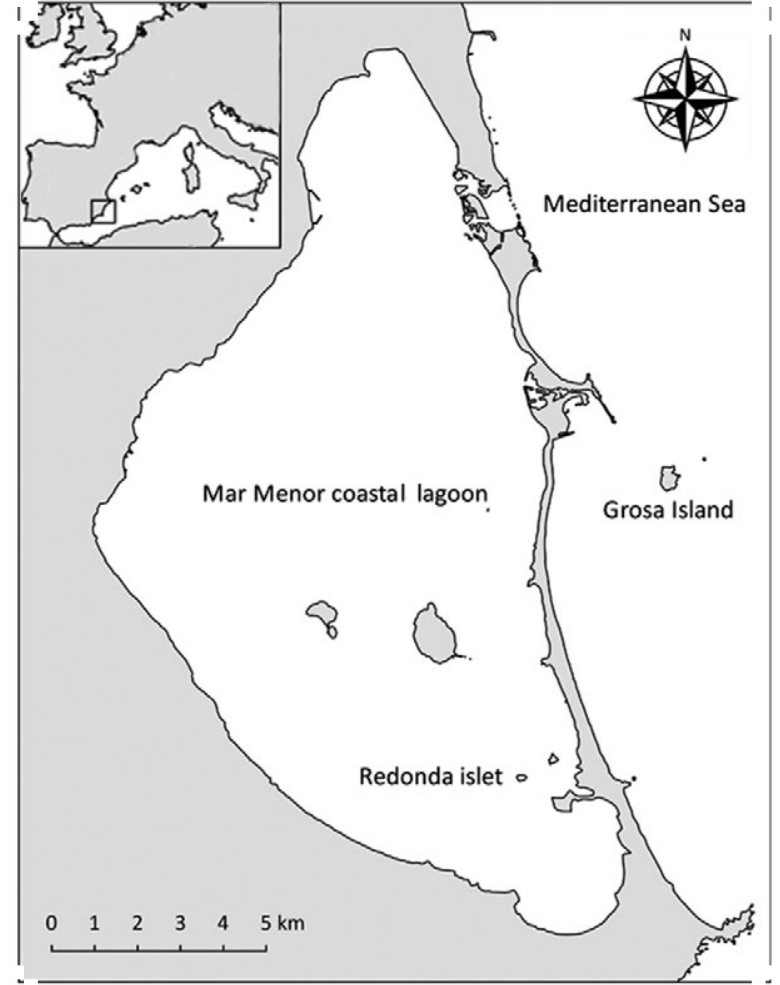

Fig. 1. - Location of the study area (western Mediterranean, region of Murcia, SE Spain: 3746'00"N, 050'00"W).

event coinciding with the chick-ringing campaign. During 2016 wintering, also in mid-February, cormorant pellets were taken from the roosting areas on Grosa Island and Redonda Islet at noon, when there were almost no cormorants in the area. For both bird species only fresh pellets were collected. Cormorants move between Grosa Island and Redonda Islet to roost on them indistinctly (Eguía-Martínez et al. 2015), so both roosting places can be considered as a single functional unit, and data from pellets obtained on the two islands were therefore considered as replicates. Each pellet was sealed individually in plastic bags, labelled and stored frozen $\left(-20^{\circ} \mathrm{C}\right)$ until processing.

\section{Diet analysis}

Pellets were processed according to Privileggi (2003). Otoliths were extracted and identified up to the lowest possible taxonomic level, comparing them with images from the atlas compiled by Tuset et al. (2008) and the manual by Artzi et al. (2009) for marine and freshwater species, respectively. From each pellet, right and left otoliths of each fish species were separated and the most numerous side was used to resolve the number of individuals from each species in the pellet. Fish species composition and total abundance were recorded for each pellet. Otolith length (OL) was also measured to the nearest $0.01 \mathrm{~mm}$ under a dissecting microscope. Fish species length (FL) was estimated using the OLFL equations from Giménez et al. (2016) and Amouei et al. (2013) for marine and freshwater fish species, respectively. Fish weight $(\mathrm{FW})$ was estimated using the FL-FW equations obtained from Froese and Pauly (2007). Strongly eroded otoliths were recorded as unidentified species. For total abundance analysis, only half the eroded otoliths were arbitrarily considered. For total biomass analysis, we assigned the average weight of all the identified species to unidentified otoliths to estimate total biomass per pellet. Considering that daily pellet production of shags (and probably cormorants) is variable through seasons (Russell et al. 1995), the daily biomass intake by shags and cormorants was estimated as a range from the average biomass estimated for each pellet, considering that both bird species may regurgitate one or two pellets per day (Johnstone et al. 1990).

\section{Statistical analyses}

Differences between shag and cormorant diet were assessed using univariate and multivariate variables. Univariate analyses were performed for species richness (number of species), total abundance (number of individuals) and total biomass per sample. Furthermore, fish species were assigned to one of the following functional groups: small pelagic, demersal, benthic and freshwater. Then, multivariate analyses were performed for functional groups in terms of both abundance and biomass. Unidentified species were not included in any multivariate analysis. One-way non-parametric permutational univariate analysis of variance (PERM-ANOVA) or multivariate analysis of variance (PERM-ANOVA) (Anderson et al. 2008) were used to test the above hypothesis. PERMANOVA was based on Euclidean distances of normalized species richness, total abundance and total biomass data, and PERM-ANOVA on the Bray-Curtis dissimilarities (Clarke and Warwick 1994) of squareroot transformed functional group data (Clarke 1993) in terms of abundance and biomass. Both univariate and multivariate analyses were tested under unrestricted 4999 permutations of raw data (Anderson 2001a). The Monte Carlo P-value (P(MC)) was also calculated and considered preferentially (Anderson 2001b, 2005). A SIMPER test was run to establish the contribution of the functional groups and fish species, in terms of both abundance and biomass, with respect to the differences between the diet of shags and cormorants during syntopy. All analyses were carried out using PRIMER-E v. 7.0.10 and PERMANOVA +1 (PRIMER-E 2015).

\section{Shag and great cormorant abundance}

Monthly abundance of shags from November 2015 to March 2016 was estimated by counting the shags in the roosting and nesting places early in the morning fortnightly, and then averaging. Monthly abundance of cormorants in the study area was assigned from abundance data derived from the 2013 winter census (Molina 2013), after considering that abundance increases progressively from the beginning of the season, reaching a maximum at the time of counting (mid-January), and then decreasing to the end of the season (as shown below). 


\section{Competition with local artisanal fisheries inside Mar Menor coastal lagoon}

Fish species identified from otoliths in shag and cormorant pellets were classified into three categories depending on their local economic importance: high, medium and low. Potential consumption of these fish species by shags and cormorants throughout the season was estimated monthly from bird abundance and average biomass intake data, according to the overall contribution of fish to the diet of shags and cormorants over the season. Artisanal fishing in the Grosa Island and Mar Menor area is carried out by the Fishermen's Association of San Pedro del Pinatar (hereafter FASP). Monthly fishing effort was estimated as a percentage in line with the range of gear allowed and deployed, as provided by the FASP. Also, the FASP provided us with monthly total catch (TC) data for the fish species of high local commercial interest which were found in the diet of shags and cormorants during syntopy, from November 2015 to March 2016.

Maximum potential catches (MPC, calculated as if the fishing effort was always $100 \%$ ) were calculated monthly and for the whole season. The TC/MPC ratio was defined as a measure of similarity between how much was captured for the fishing effort applied (TC) and how much could have been captured if the fishing effort had been the maximum every month (MPC). TC/ MPC was calculated for the whole season. This ratio goes from 0 to 1 , so the less close to 1 , the higher the possibility of competition.

\section{RESULTS}

A total of 18 shag pellets were collected at nests on Grosa Island, and 78 cormorant pellets were removed from their roosting places on Grosa Island and Redonda Islet. Altogether, a total of 2130 otoliths were obtained, of which $10.4 \%$ were too eroded and were recorded as unidentified. A total of 1065 fish were identified, belonging to 14 families and 23 species. Mugilidae were identified only up to family level. Table 1 shows the species composition of shag and cormorant diet in terms of abundance and biomass, as well as the assignation of fish species to functional groups and categories of economic importance.

\section{Comparing the diet of shags and cormorants}

Species richness and total abundance in the diet (Table 2) were higher (PERM-ANOVA, Pseudo- $\mathrm{F}_{2}$, ${ }_{62}=9.11$ and 9.24, respectively; $\mathrm{P}<0.01$ and $\mathrm{P}<0.001$, respectively) for shag than for cormorant. However, no differences were detected for total biomass between the two species (PERM-ANOVA, Pseudo- $\mathrm{F}_{2,62}=0.53$; $P>0.05)$. Despite this, estimated daily biomass intake was slightly higher for cormorant than for shag (Table 2). In terms of both abundance and biomass, shags preyed mostly on small pelagic fish and cormorants on demersal fish (PERM-ANOVA, Pseudo $-\mathrm{F}_{2,62}=8.76$ and 20.04, respectively; $\mathrm{P}<0.001$ for both) (Table 3 ). Benthic fish was the functional group least predated on by both bird species. Freshwater fish were present only in cormorant diet.

In shag diet, the most abundant fish species in increasing order were Boops boops (40.9\%), Trisopterus sp. (14.3\%) and Coris julis (10.3\%), and the greatest biomass was obtained from B. boops $(46.1 \%), C$. julis $(12.8 \%)$ and Diplodus annularis $(7.9 \%)$. In cormorant diet, the most abundant preys in increasing order were Sparus aurata (35.3\%), Atherina boyeri (12.6\%), Cyprinus carpio (12.2\%) and Dicentrarchus labrax (10.1\%), and the greatest biomass was obtained from $S$. aurata $(43.8 \%)$, D. labrax $(17.1 \%)$, C. carpio $(9.9 \%)$ and Mugilidae (9.1\%) (Table 1). The SIMPER test revealed that the fish species which most contributed

Table 1. - Species composition obtained from shag and great cormorant pellet analysis, expressed in terms of abundance and biomass as \% with respect to the total (mean \pm standard error), and assignation of fish species to functional groups (SP, small pelagic; B, benthic; D, demersal; FW, freshwater) and commercial interest (H, high; M, medium; L, low) categories.

\begin{tabular}{|c|c|c|c|c|c|c|c|}
\hline \multirow{2}{*}{ Family } & \multirow{2}{*}{ Species } & \multirow{2}{*}{$\begin{array}{l}\text { Functional } \\
\text { groups }\end{array}$} & \multirow{2}{*}{$\begin{array}{c}\text { Commercial } \\
\text { interest }\end{array}$} & \multicolumn{2}{|c|}{ Shag $(n=18)$} & \multicolumn{2}{|c|}{ Cormorant $(\mathrm{n}=78)$} \\
\hline & & & & Abundance $(\%)$ & Biomass $(\%)$ & Abundance $(\%)$ & Biomass $(\%)$ \\
\hline Atherinidae & Atherina boyeri & SP & $\mathrm{H}$ & $3.03 \pm 3.03$ & $2.60 \pm 2.60$ & $12.66 \pm 3.09$ & $2.03 \pm 0.90$ \\
\hline Centracanthidae & Spicara smaris & SP & $\mathrm{H}$ & $3.02 \pm 2.03$ & $1.81 \pm 1.27$ & $2.47 \pm 1.35$ & $1.36 \pm 0.77$ \\
\hline Cyprinidae & Cyprinus carpio & $\mathrm{FW}$ & $\mathrm{L}$ & - & - & $12.20 \pm 3.85$ & $9.99 \pm 3.52$ \\
\hline Gadidae & Trisopterus sp. & SP & $\mathrm{L}$ & $14.32 \pm 6.90$ & $6.23 \pm 3.42$ & - & - \\
\hline \multirow[t]{2}{*}{ Gobiidae } & Gobius cruentatus & B & $\mathrm{L}$ & $5.88 \pm 5.45$ & $6.06 \pm 0.01$ & $3.93 \pm 1.61$ & $0.97 \pm 0.68$ \\
\hline & Gobius paganellus & B & $\mathrm{L}$ & $1.32 \pm 0.60$ & $1.21 \pm 0.53$ & $0.75 \pm 0.48$ & $0.69 \pm 0.64$ \\
\hline Haemulidae & Pomadasys incisus & $\mathrm{D}$ & $\mathrm{M}$ & - & - & $0.84 \pm 0.59$ & $0.12 \pm 0.08$ \\
\hline \multirow[t]{2}{*}{ Labridae } & Coris julis & $\mathrm{D}$ & $\mathrm{L}$ & $10.36 \pm 3.81$ & $12.80 \pm 6.06$ & $\begin{array}{c}0.0+100 \\
-\end{array}$ & $\begin{array}{c}0.00 \\
-\end{array}$ \\
\hline & Labrus merula & $\mathrm{D}$ & $\mathrm{L}$ & $3.14 \pm 1.48$ & $0.47 \pm 0.24$ & - & - \\
\hline Moronidae & Dicentrarchus labrax & $\mathrm{D}$ & $\mathrm{H}$ & $5.45 \pm 3.85$ & $2.71 \pm 1.98$ & $10.12 \pm 3.13$ & $17.16 \pm 4.51$ \\
\hline Mugilidae & Mugilidae & $\mathrm{D}$ & $\mathrm{H}$ & - & - & $3.10 \pm 1.84$ & $9.10 \pm 4.81$ \\
\hline Mullidae & Mullus barbatus & $\mathrm{B}$ & $\mathrm{H}$ & $0.82 \pm 0.82$ & $1.52 \pm 1.60$ & $0.14 \pm 0.14$ & $0.32 \pm 0.32$ \\
\hline Muraenidae & Muraena helena & $\mathrm{B}$ & M & - & - & $1.88 \pm 1.88$ & $1.88 \pm 1.88$ \\
\hline Sciaenidae & Sciaena umbra & $\mathrm{B}$ & $\mathrm{H}$ & - & - & $0.02 \pm 0.02$ & $0.35 \pm 0.35$ \\
\hline Serranidae & Serranus cabrilla & $\mathrm{D}$ & M & - & - & $0.53 \pm 0.53$ & $0.14 \pm 0.14$ \\
\hline \multirow[t]{8}{*}{ Sparidae } & Boops boops & SP & M & $40.99 \pm 9.63$ & $46.12 \pm 9.20$ & $4.72 \pm 1.84$ & $4.39 \pm 1.99$ \\
\hline & Diplodus puntazzo & $\mathrm{D}$ & $\mathrm{H}$ & - & - & $8.60 \pm 2.16$ & $3.39 \pm 0.96$ \\
\hline & Diplodus annularis & $\mathrm{D}$ & $\mathrm{H}$ & $8.17 \pm 5.42$ & $7.94 \pm 4.61$ & $2.29 \pm 1.02$ & $1.77 \pm 1.02$ \\
\hline & Lithognathus mormyrus & $\mathrm{B}$ & $\mathrm{H}$ & $0.14 \pm 0.14$ & $10.02 \pm 5.67$ & - & - \\
\hline & Oblada melanura & $\mathrm{D}$ & M & $0.14 \pm 0.14$ & $0.05 \pm 0.05$ & - & - \\
\hline & Pagrus pagrus & $\mathrm{D}$ & $\mathrm{H}$ & $0.53 \pm 0.53$ & $0.39 \pm 0.39$ & - & - \\
\hline & Sarpa salpa & $\mathrm{B}$ & M & - & - & $0.31 \pm 0.31$ & $1.37 \pm 1.37$ \\
\hline & Sparus aurata & $\mathrm{D}$ & $\mathrm{H}$ & - & - & $35.31 \pm 4.41$ & $43.84 \pm 5.09$ \\
\hline
\end{tabular}


Table 2. - Shag and great cormorant species richness, total prey abundance and biomass per pellet sample (mean \pm standard error), and daily biomass intake range [g day ${ }^{-1}$, as estimated according to Johnstone et al. (1990): 1-2 pellets day ${ }^{-1}$ ]. Different superscript letters indicate significant differences.

\begin{tabular}{lcccc}
\hline & Species richness & Total abundance & Total biomass & Daily intake (min-mean-max) \\
\hline Shag & $4.36 \pm 0.31^{\mathrm{a}}$ & $19.71 \pm 5.23^{\mathrm{a}}$ & $220.81 \pm 29.45^{\mathrm{a}}$ & $220-330-440$ \\
Great cormorant & $2.81 \pm 0.18^{\mathrm{b}}$ & $9.09 \pm 1.64^{\mathrm{b}}$ & $274.16 \pm 33.61^{\mathrm{a}}$ & $274-412-548$ \\
\hline
\end{tabular}

Table 3. - Abundance and biomass of fish functional groups (\%; mean \pm standard error) included in shag and cormorant diet. Different superscript letters indicate significant differences between shag and cormorant during syntopy. SP, small pelagic; B, benthic; D, demersal; FW, freshwater.

\begin{tabular}{|c|c|c|c|c|}
\hline Functional groups & SP & $\mathrm{D}$ & B & FW \\
\hline \multicolumn{5}{|l|}{ Abundance (\%) } \\
\hline Shag a & $61.38 \pm 9.51$ & $27.53 \pm 8.96$ & $11.09 \pm 5.75$ & - \\
\hline Cormorant ${ }^{b}$ & $19.90 \pm 3.69$ & $60.30 \pm 4.98$ & $7.60 \pm 2.74$ & $12.20 \pm 3.88$ \\
\hline \multicolumn{5}{|l|}{ Biomass (\%) } \\
\hline Shag a & $56.78 \pm 9.10$ & $24.39 \pm 7.86$ & $18.84 \pm 7.43$ & - \\
\hline Cormorant ${ }^{b}$ & $8.83 \pm 2.60$ & $75.42 \pm 4.76$ & $5.76 \pm 2.66$ & $9.99 \pm 3.55$ \\
\hline
\end{tabular}

Table 4. - Minimum, mean and maximum size (fork length in $\mathrm{cm}$ ) of shag and great cormorant preys.

\begin{tabular}{|c|c|c|c|c|c|c|c|}
\hline \multirow[b]{2}{*}{ Family } & \multirow[b]{2}{*}{ Species } & \multicolumn{3}{|c|}{ Shag } & \multicolumn{3}{|c|}{ Great cormorant } \\
\hline & & Min. & Mean & Max. & Min. & Mean & Max. \\
\hline Atherinida & Atherina boyerii & 4.72 & 6.53 & 8.69 & 4.52 & 6.57 & 9.58 \\
\hline Centracanthidae & Spicara smaris & 9.38 & 10.20 & 12.27 & 5.87 & 8.32 & 13.42 \\
\hline Cyprinidae & Cyprinus carpio & - & - & - & 8.89 & 10.01 & 14.10 \\
\hline Gadidae & Trisopterus sp. & 3.21 & 7.79 & 10.17 & - & - & - \\
\hline \multirow[t]{2}{*}{ Gobiidae } & Gobius cruentatus & 3.43 & 6.08 & 9.23 & 4.23 & 6.18 & 8.74 \\
\hline & Gobius paganellus & 4.65 & 8.02 & 10.86 & 5.18 & 7.10 & 10.86 \\
\hline Haemulidae & Pomadasys incisus & - & - & - & 6.76 & 8.04 & 9.32 \\
\hline \multirow[t]{2}{*}{ Labridae } & Coris julis & 5.83 & 11.63 & 17.37 & - & - & - \\
\hline & Labrus merula & 3.50 & 5.65 & 8.06 & - & - & - \\
\hline Moronidae & Dicentrarchus labrax & 6.34 & 8.07 & 9.72 & 11.76 & 22.33 & 30.91 \\
\hline Mugilidae & Mugilidae & - & - & - & 7.31 & 27.14 & 50.85 \\
\hline Mullidae & Mullus barbatus & 15.75 & 15.75 & 15.75 & - & - & - \\
\hline Muraenidae & Muraena helena & - & - & - & 35.80 & 35.80 & 35.80 \\
\hline Sciaenidae & Sciaena umbra & - & - & - & 14.34 & 14.34 & 14.34 \\
\hline Serranidae & Serranus cabrilla & - & - & - & 9.49 & 10.48 & 11.46 \\
\hline \multirow{10}{*}{ Sparidae } & Boops boops & 8.25 & 12.05 & 17.73 & 10.05 & 13.06 & 18.80 \\
\hline & Diplodus puntazzo & - & - & - & 6.16 & 9.17 & 12.33 \\
\hline & Diplodus annularis & 5.55 & 9.87 & 13.62 & 7.48 & 10.73 & 14.07 \\
\hline & Lithognathus mormyrus & 13.26 & 15.32 & 19.42 & - & - & - \\
\hline & Oblada melanura & 6.68 & 10.25 & 13.99 & & & \\
\hline & Pagrus pagrus & 9.15 & 9.15 & 9.15 & - & - & - \\
\hline & Sarpa salpa & 0 & 0 & 0 & 27.20 & 27.20 & 27.20 \\
\hline & Sparus aurata & - & - & - & 8.93 & 13.87 & 20.66 \\
\hline & Overall size & 3.21 & 9.70 & 19.42 & 4.23 & 14.40 & 50.85 \\
\hline & Modal size & & 8.74 & & & 6.51 & \\
\hline
\end{tabular}

to differences between shag and cormorant diet with regard to abundance were B. boops and Trisopterus sp. with a greater abundance in shag diet, and $S$. aurata and $A$. boyeri with a greater abundance in cormorant diet. As for biomass, differences between shag and cormorant were supported by the higher biomass in shag diet of B. boops and, to a lesser extent, $C$. julis (absent in the cormorant diet), and also to higher biomass in cormorant diet of $S$. aurata (absent in the shag diet) and D. labrax. Average size of cormorant prey was considerably greater $(14.40 \mathrm{~cm})$ than that of shags $(9.70 \mathrm{~cm})$, particularly in the case of D. labrax. Exceptionally, cormorant preyed on very large fish, such as a Mugilidae specimen of almost $51 \mathrm{~cm}$ (Table 4). For shag and cormorant, modal prey size (8.74 and 6.51 $\mathrm{cm}$, respectively) was lower than mean size (Table 4).

\section{Shag and cormorant abundance}

Monthly abundance of shag showed no large variations, ranging from 23 to 43 individuals throughout the season around Grosa Island (Table 5). For cormorant, we assigned an increasing abundance from the beginning to the middle of the season, from which it descended to the end of the season, based on a maximum abundance of $c a .5000$ specimens in the middle of the season at Grosa Island and Redonda Islet jointly, in agreement with Molina (2013), as shown in Table 5.

\section{Fishing catch of species of high commercial value and consumption by shags and cormorants}

The fish species of high commercial interest (Table 1) captured by FASP fishermen which were also found in shag and/or cormorant diet were S. aurata, D. labrax, $A$. boyeri, Mugilidae and $D$. annularis. For these species, Table 5 shows monthly fishing effort, TC data, fishing MPC and the overall TC/MPC ratio. Fishing effort was the maximum possible during November 2015, dropping progressively in winter and increasing in early spring. Conversely, fishing effort on $A$. boyeri was low at the beginning of the season, increasing 
Table 5. - Monthly fishing effort (FE), total catch (TC) and maximum potential catches (MPC) of high commercial interest fish species by FASP fishermen, and estimated monthly shag and great cormorant intake. Abundance of shag and great cormorant during 2016 breedingwintering season.

\begin{tabular}{|c|c|c|c|c|c|c|c|c|}
\hline & & Nov 2015 & Dec 2015 & Jan 2016 & Feb 2016 & March 2016 & Total & Competition \\
\hline \multirow[t]{6}{*}{ Sparus aurata } & $\mathrm{FE}(\%)$ & 100 & 75 & 30 & 30 & 50 & & \\
\hline & $\mathrm{TC}(\mathrm{kg})$ & 63776 & 1083 & 627 & 2197 & 3563 & 71246 & \\
\hline & $\operatorname{MPC}(\mathrm{kg})$ & 63776 & 1444 & 2090 & 7323 & 7126 & 81759 & \\
\hline & TC/MPC & & & & & & 0.87 & \\
\hline & Shag intake $(\mathrm{kg})$ & 0 & 0 & 0 & 0 & 0 & 0 & - \\
\hline & Cormorant intake $(\mathrm{kg})$ & 6773 & 20320 & 27093 & 20320 & 6773 & 81279 & - \\
\hline \multirow[t]{6}{*}{ Dicentrarchus labrax } & $\mathrm{FE}(\%)$ & 100 & 75 & 30 & 30 & 50 & & \\
\hline & $\mathrm{TC}(\mathrm{kg})$ & 3113 & 3654 & 2178 & 1145 & 832 & 10922 & \\
\hline & MPC (kg) & 3113 & 4872 & 7260 & 3817 & 1664 & 20726 & \\
\hline & TC/MPC & & & & & & 0.52 & \\
\hline & Shag intake (kg) & 6 & 11 & 8 & 12 & 9 & 46 & - \\
\hline & Cormorant intake $(\mathrm{kg})$ & 2651 & 7954 & 10605 & 7954 & 2651 & 31815 & + \\
\hline \multirow[t]{6}{*}{ Atherina boyeri } & $\mathrm{FE}(\%)$ & 10 & 10 & 50 & 75 & 100 & & \\
\hline & $\mathrm{TC}(\mathrm{kg})$ & 31 & 189 & 588 & 2092 & 7494 & 10394 & \\
\hline & MPC (kg) & 310 & 1890 & 1176 & 2789 & 7494 & 13659 & \\
\hline & TC/MPC & & & & & & 0.76 & \\
\hline & Shag intake $(\mathrm{kg})$ & 6 & 10 & 8 & 11 & 9 & 44 & - \\
\hline & Cormorant intake $(\mathrm{kg})$ & 314 & 941 & 1255 & 941 & 314 & 3764 & - \\
\hline \multirow[t]{6}{*}{ Mugilidae } & $\mathrm{FE}(\%)$ & 100 & 75 & 30 & 30 & 50 & & \\
\hline & $\mathrm{TC}(\mathrm{kg})$ & 1669 & 823 & 1284 & 856 & 1146 & 5778 & \\
\hline & $\operatorname{MPC}(\mathrm{kg})$ & 1669 & 1097 & 4280 & 2853 & 2292 & 12192 & \\
\hline & TC/MPC & & & & & & 0.47 & \\
\hline & Shag intake $(\mathrm{kg})$ & 0 & 0 & 0 & 0 & 0 & 0 & - \\
\hline & Cormorant intake $(\mathrm{kg})$ & 1406 & 4218 & 5624 & 4218 & 1406 & 16871 & + \\
\hline \multirow[t]{8}{*}{ Diplodus annularis } & $\mathrm{FE}(\%)$ & 100 & 75 & 30 & 30 & 50 & & \\
\hline & $\mathrm{TC}(\mathrm{kg})$ & 1608 & 164 & 1 & 98 & 126 & 1997 & \\
\hline & MPC $(\mathrm{kg})$ & 1608 & 219 & 3 & 327 & 252 & 2409 & \\
\hline & TC/MPC & & & & & & 0.82 & \\
\hline & Shag intake (kg) & 18 & 31 & 24 & 34 & 27 & 134 & - \\
\hline & Cormorant intake $(\mathrm{kg})$ & 273 & 820 & 1094 & 820 & 273 & 3282 & + \\
\hline & Shag abundance & $23 \pm 11$ & $40 \pm 15$ & $30 \pm 9$ & $43 \pm 19$ & $34 \pm 19$ & & \\
\hline & Cormorant abundance & 1250 & 3750 & 5000 & 3750 & 1250 & & \\
\hline
\end{tabular}

Table 6. - Proportion (\%; mean \pm standard error) of fish with high $(\mathrm{H})$, medium (M) and low (L) commercial value preyed on by shag and cormorant.

\begin{tabular}{lccc}
\hline & $\mathrm{H}$ & $\mathrm{M}$ & $\mathrm{L}$ \\
\hline Shag & $25.21 \pm 7.83$ & $47.99 \pm 10.29$ & $26.80 \pm 7.25$ \\
Cormorant & $79.04 \pm 4.52$ & $9.30 \pm 3.04$ & $11.66 \pm 3.71$ \\
\hline
\end{tabular}

gradually up to its maximum in early spring. For the study period, the increasing order of catch by species corresponds to the species listed above. S. aurata was captured profusely, and seasonal TC data constituted an absolute historical record (FASP, pers. comm.). $S$. aurata and D. labrax TC decreased as the season progressed, unlike $A$. boyeri, Mugilidae and $D$. annularis TC, which were irregular throughout the season. TC/ MPC values for the whole season reveal that catches of $S$. aurata (0.87) and D. annularis (0.82), and to a lesser extent $A$. boyeri $(0.75)$, were close to the maximum possible for FASP over the study period, but $D$. lab$\operatorname{rax}(0.52)$ and Mugilidae (0.47) could have been more abundant, so competition for the two latter species was alike. It is noteworthy that catches of $D$. annularis by cormorants could be higher than the expected MPC.

Monthly consumption of fish species of high commercial value by shags and cormorants is shown in Table 5. Shag biomass intake was derived mainly from fish species of medium commercial value (47.9\%), while the diet of cormorant was composed largely of species of high commercial value (79.0 \%) (Table 6). Biomass intake by shags throughout the season was very low for all five fish species. Only $D$. annularis intake exceeded $100 \mathrm{~kg}$ for the whole season. For no fish species did the biomass consumed by shags exceed the fishing MPC. Cormorants consumed a considerable biomass of the five species, particularly $S$. aurata, $D$. labrax and Mugilidae. Biomass intake of D. labrax, Mugilidae and $D$. annularis by cormorants exceeded the fishery MPC.

\section{DISCUSSION}

Shag diet was mainly based on small pelagic fish species, but demersal fish are also an important resource. The shag diet is more varied and focused on smaller prey than the cormorant diet during syntopy in the study area, but the size range of cormorant preys is larger. Cormorants fed mainly on demersal fish, so there is no sign of competition with shags throughout their syntopic period. Likewise, there is no suspicion of competition between shags and local fishermen. However, cormorants may compete with local fishermen for D. labrax, Mugilidae and, to a lesser extent, for $D$. annularis.

Composition of shag diet has been studied at different places and seasons in the Atlantic and the Mediterranean, mainly from otoliths in regurgitated pellets (Velando and Freire 1999, Al-Ismail et al. 2013, Morat et al. 2014), but also by assessing stomach content (Lilliendahl and Solmundsson 2006), or using combined methods (Harris and Wanless 1993). These studies 
agree on the variety in shag diet, revealing geographical differences in diet composition and biomass intake, and variations over time related to the life-cycle phase and resource availability. The diet of the Atlantic shag subspecies ( $P$. a. aristotelis) is mainly composed of sand-eels (Ammodytes spp.), and some authors have therefore suggested some degree of specialization (Harris and Wanless 1993, Velando and Freire 1999). Shag diet composition depends on habitat diversity in the foraging area, which will largely determine prey diversity and availability. Local environmental conditions strongly affect fish recruitment, which also influences species composition and abundance (Myers 1997). Availability of local resources at a given time seems to be the main driver of diet composition for shags (Carss 1993, Lilliendahl and Solmundsson 2006). In our case, prey availability was unknown, so we hypothesize that for the studied season shag must feed on the most abundant species. Therefore, they could be considered as truly adaptable opportunists. Not surprisingly, some authors suggest the possibility of studying local resource availability based on the diet composition of this bird (Barrett et al. 1990, Barrett 1991). Some studies suggest that Atlantic shag is a predominantly benthic feeder (Wanless et al. 1998, Watanaki et al. 2008). Our results revealed that in the study area shags fed predominantly on small-size pelagic fish (B. boops, Trisopterus sp.), though demersal resources $(C$. julis, $D$. annularis) were also important in their diet. These results agree with those of Al-Ismail et al. (2013) studying shag diet in Mallorca (Balearic Islands) regardless of differences in the submerged habitat. In our study, the shag foraging area includes a vast Posidonia oceanica meadow, wide shallow sandy bottoms and, to a lesser extent, rocky reefs (MAPAMA 2017). Most fish species identified here are totally or partially linked to the meadow, even small pelagic species (Cetinić et al. 2011). Small-size B. boops, Trisopterus sp. and Spicara smaris form large shoals at different depths in the water column over the meadow canopy, where they find food and some shelter from predators. Therefore, these species may behave as purely pelagic but also as demersal (epibenthic) occasionally, and then shags may capture them both in the water column and near the bottom. Assignation of fish to a particular functional group is somewhat controversial, increasing discrepancies with regard to considering shags pelagic, demersal or benthic feeders. Nevertheless, most authors agree on the importance of the seabed in provisioning this bird, and also its foraging flexibility (Wanless et al. 1991b, Grémillet et al. 1998, Cosolo et al. 2011).

Our study reveals that shags prey preferably on small pelagic fish and cormorants on demersal fish. Similar results were obtained by Lillendahl and Solmundsson (2006) in Iceland. Conversely, shag diet was more diverse than cormorant diet during their period of syntopy around Grosa Island than in Iceland. However, both species show a noteworthy dietary variability at different spatial and temporal scales. We estimated that shag daily biomass intake was slightly less (but the difference was not statistically significant) than that of cormorant, in agreement with the results of Grémillet et al. (1996, 1998). However, shag mean prey size was smaller than that of cormorant, so shags had to compensate for the small size of preys caught by intensifying catch effort and number of prey per feeding event to obtain a comparable biomass. Barrett et al. (1990) and Lillendahl and Solmundsson (2006) also found that cormorant preys tend to be larger than those of shag. Consistently, cormorants from our study area needed less than half the prey numbers of shags to achieve their daily intake, due to the ability of cormorant to hunt larger fish. Differences in mean prey size between shag and cormorant could be related to differences in bill size. Though mean prey size of cormorant is larger than that of shag, the former also hunted small prey frequently, mainly A. boyeri. This meant that their prey modal size was even smaller than that of shags. However, the contribution of those small fish to the diet of cormorant was very low in terms of biomass intake.

The differences in diet composition between shag and cormorant during syntopy were notable, and the species most represented in their diets also differed. Therefore, it seems that trophic competition, as we expected, did not occur between these two coexisting bird species around Grosa Island. Lillendahl and Solmundsson (2006) also noticed segregation in diets of Icelandic shags and cormorants in syntopy. A partial spatial segregation in our study area between the two coexisting birds with regard to their preferred fishing zones must also explain the lack of competition. While the shag is a strictly marine bird, cormorants forage both in the open sea and inside the coastal lagoon, and even in fresh water irrigation ponds and reservoirs on the mainland tens of kilometres inland (Farinós and Robledano 2010), where they prey on C. carpio. This freshwater fish represented a considerable fraction in their diet (about $10 \%$ in biomass). In Spain, C. carpio is considered an exotic invasive species included in eradication programmes (BOE 2013), so its consumption by cormorants can be considered an ecosystem service (Constanza et al. 1997). This pattern agrees with Mizutani et al. (1990), who observed that large groups of great cormorants ( $>2000$ individuals) tend to segregate spatially to forage over an environmental gradient, in our case alternating between marine waters, the coastal lagoon and inland freshwater bodies. Conversely, shags rarely enter the coastal lagoon and never forage in inland ponds, but forage in the open sea most of the time.

Considering the low shag population density, their low predation on FASP target species and the facts that most fishing effort is focused inside the lagoon where shags rarely forage, there is virtually no interaction between shag and fishermen in the study area. Morat et al. (2014) did not observe major competition between shags and fisheries on the French Mediterranean coast either. However, in other places where shag population density is higher, they might affect commercially important fish stocks (Barrett et al. 1990, Lillendahl and Solmundsson 2006). Unlike shag, cormorants enter and leave the Mar Menor frequently, investing considerable fishing effort inside the lagoon during autumn and 
winter months. Taking into account the FASP fishing effort for those months and the estimated cormorant biomass intake, our results reveal that cormorants may compete for some commercially targeted fish such as $D$. labrax, and Mugilidae species and, to a lesser extent, for $D$. annularis. The magnitude of this interaction might change depending on fish availability, fishing effort and variations in cormorant population density. However, such a high consumption of $S$. aurata by cormorants does not automatically mean there is competition over fish resources, in accordance with Östman et al. (2013), especially if we consider that FASP beat the previous catch record for this species in the Mar Menor during the studied season (FASP, pers. comm). Regarding $D$. annularis, it seems that cormorants are more efficient than the recruitment to the fishing gear. A side-effect of the intense interaction between cormorants and fisheries is the high mortality of cormorants (about $10 \%$ of the wintering population in 2014), most of them young and sub-adult specimens trapped in fishing nets deployed in the Mar Menor (Zamora 2015).

Geographical and temporal variability in diet composition of shags and cormorants may cause varied intensities of competition with fisheries (Östman et al. 2013), from minimal (Liordos and Goutner 2007) to strong competition (Steffens 2011). Measures to prevent economic impact on fisheries caused by cormorants are mostly focused on the control of nesting at breeding grounds through egg-oiling or nest destruction, and of population density at nesting and wintering places through harassment or culling. However, the effectiveness of all these measures is in question (Carss 2002, Taylor and Dorr 2003). At Grosa Island and in the Mar Menor area, no management actions are implemented to deal with this interaction. To the complaints of fishermen regarding cormorant catches, we must add those of conservationist organizations about the high fishing effort and accidental bird by-catches which include not only cormorant but also ducks, gulls and grebes (Zamora 2015). Therefore, it seems obvious that the sustainability of natural resources will not have to focus only on controlling cormorant wintering population, but also on preventing fishing side-effects and managing fishing effort of both fishermen and cormorants.

\section{ACKNOWLEDGEMENTS}

The authors thank Beatriz López Pastor, Francisco García Castellanos, Ángel Sallent, Gonzalo G. Barberá, Pedro García and Mario León for their help in collecting pellets at nest and roost sites, and the Office of Socio-Economic Impact of the Environment (Department of Agriculture, Water and Environment of Murcia, Spain) for facilitating access to shag and cormorant breeding and roosting places. The authors are very grateful to the two reviewers for comments and suggestions that improved the final version of the manuscript. This research was funded by the Autonomous Government of Murcia, Spain (Department of Agriculture, Water and Environment) (Regional Programme co-funded by FEDER, project grant number RM-POI-07-043).

\section{REFERENCES}

Al-Ismail S., McMinn M., Tuset V.M., et al. 2013. Summer diet of European shags Phalacocorax aristotelis desmarestii in southern Mallorca. Seabird 26: 8-23.

Amouei F., Valinassab T., Haitov A. 2013. Age determination and morphological study using otoliths in Cyprinus carpio Linnaeus, 1758 in the southern Caspian Sea Iranian. J. Fish. Sci. 12: 759-769.

Anderson M.J. 2001a. A new method for non-parametric multivariate analysis of variance. Aust. Ecol. 26: 32-46. https://doi.org/10.1111/j.1442-9993.2001.01070.pp.x

Anderson M.J. 2001b. Permutation tests for univariate or multivariate analysis of variance and regression. Can. J. Fish. Aquatic Sci. 58: 626-639. https://doi.org/10.1139/f01-004

Anderson M.J. 2005. PERMANOVA. Permutational Multivariate Analysis of Variance. A Computer Program. Department of Statistics, University of Auckland, NZ, 24 pp.

Anderson M.J., Gorley R.N., Clarke K.R. 2008. PERMANOVA+ for PRIMER: guide to software and statistical methods. PRIMER-E, Plymouth.

Artzi Y., Gisis G., Goldstein H. 2009. Manual for freshwater fishotoliths-Israel. Israel Natural and Parks Authority, 21 pp. http://www.nature-conservation.org.il/BuildaGate5/portals/ conserve/imagesP/sub72/725026172.pdf

Barrett R.T. 1991. Shags (Phalacrocorax aristotelis L.) as potential samplers of juvenile saithe (Pollachius virens (L.)) stocks in northern Norway. Sarsia 76: 153-156. https://doi.org/10.1080/00364827.1991.10413470

Barrett R.T., Røv N., Loen J., et al. 1990. Diets of Shags Phalacrocorax aristotelis and Cormorants $P$. carbo in Norway and possible implications for gadoid stock recruitment. Mar. Ecol. Prog. Ser. 66: 205-218 https://doi.org/10.3354/meps066205

Barros A., Álvarez D., Velando A. 2013. Cormorán moñudo Phalacrocorax aristotelis. In: Salvador A., Morales M.B. (eds), Enciclopedia Virtual de los Vertebrados Españoles. Museo Nacional de Ciencias Naturales, Madrid. http://www.vertebradosibericos.org

BOE. 2013. Real Decreto 630/2013, de 2 de Agosto, por el que se regula el Catálogo español de especies exóticas invasoras. Boletín Oficial del Estado 185: 56764-56786. http://www.boe.es/boe/dias/2013/08/03/pdfs/BOE-A-20138565.pdf

Carss D.N. 1993. Shags Phalacrocorax aristotelis at cage fish farms in Argyll, western Scotland. Bird Study 40: 203-211. https://doi.org/10.1080/00063659309477184

Carss D.N. 2002. Reducing the conflict between Cormorants and fisheries on a pan-European scale (REDCAFE). Final Report. Natural Environmental Research Council. Centre for Ecology and Hydrology. http://www.intercafeproject.net/pdf/REDCAFEFINALREPORT.pdf

Carss D.N., Bevan R.M., Bonetti A., et al. 1997. The Diet Assessment and Food Intake Working Group. Techniques for assessing cormorant diet and food intake: towards a consensus view. Suppl. Ricerche Biol. Selvaggina 26: 197-230.

Cetinić P., Škeljo F., Ferri J. 2011. Discards of the commercial boat seine fisheries on Posidonia oceanica beds in the eastern Adriatic. Sci. Mar. 75: 289-300. https://doi.org/10.3989/scimar.2011.75n2289

Clarke K.R. 1993. Non-parametric multivariate analyses of changes in community structure. Aust. J. Ecol. 18: 117-143. https://doi.org/10.1111/j.1442-9993.1993.tb00438.x

Clarke K.R., Warwick R.M. 1994. Change in marine communities: an approach to statistical analysis and interpretation. PRIMERE, Plymouth.

Cosolo M., Privileggi N., Cimador B., et al. 2011. Dietary changes of Mediterranean shags Phalacrocorax aristotelis desmarestii between the breeding and post-breeding seasons in the upper Adriatic Sea. Bird Study 58: 461-472. https://doi.org/10.1080/00063657.2011.603290

Constanza R., d'Arge R., de Groot R., et al. 1997. The value of the world's ecosystem and natural capital. Nature 387: 253-260. https://doi.org/10.1038/387253a0

Cramp S., Simmons K.E.L. (eds). 1977. Handbook of the Birds of Europe, the Middle East and North Africa. The Birds of the Western Palearctic. Volume 1. Oxford University Press, Oxford. 
Duffy D.C., Laurenson I.J.R. 1983. Pellets of Cape Cormorants as indicators of diet. Condor 85: 305-307. https://doi.org/10.2307/1367066

Eguía-Martínez S., Aguado-Giménez F., Sallent A., et al. 2015. Evolución de la población nidificante de cormorán moñudo en la Región de Murcia. Proceedings of the 5th Congreso de la Naturaleza de la Región de Murcia y II del Sureste Ibérico. Asociación de Naturalistas del Sureste. Murcia, Noviembre 2015. http://www.asociacionanse.org/download/62

Farinós P., Robledano F. 2010. Structure and distribution of the waterbird community in the Mar Menor coastal lagoon (SE Spain) and relationships with environmental gradients. Waterbirds 33: 479-493. https://doi.org/10.1675/063.033.0407

Fonteneau F., Paillisson J.M., Marion L. 2009. Relationships between bird morphology and prey selection in two sympatric Great Cormorant Phalacrocorax carbo subspecies during winter. Ibis 151: 286-298. https://doi.org/10.1111/j.1474-919X.2009.00909.x

Froese R., Pauly D. 2007. FishBase. World Wide Web electronic publication. http://www.fishbase.org

Giménez J., Manjabacas A., Tuset V.M., et al. 2016. Relationship between otolith and fish size from Mediterranean and northeastern Atlantic species to be used in predator-prey studies. J. Fish Biol. 89: 2195-2202. https://doi.org/10.1111/jfb.13115

Grémillet D., Wanless S., Harris M.P., et al. 1996. Determining food intake by great cormorants and European shags with electronic balances. J. Field Ornithol. 67: 637-648.

Grémillet D., Argentin G., Schulte B. et al. 1998. Flexible foraging techniques in breeding Cormorants Phalacrocorax carbo and Shags Phalacrocorax aristotelis: benthic or pelagic feeding? Ibis 140: 113-119. https://doi.org/10.1111/j.1474-919X.1998.tb04547.x

Harris M.P., Wanless S. 1993. The diet of shag Phalacrocorax aristotelis during the chick-rearing period assessed by three methods. Bird Study 40: 135-139. https://doi.org/10.1080/00063659309477138

Harrison P. 2003. Seabirds: an identification guide. Ediciones Omega. Barcelona.

Hillers $\varnothing y$ G., Lorentsen S.-H. 2012. Annual variation in the diet of breeding European shag (Phalacrocorax aristotelis) in central Norway. Waterbirds 35: 420-429. https://doi.org/10.1675/063.035.0306

Johansen R., Barrett R.T., Pedersen T. 2001. Foraging strategies of great cormorant Phalacrocorax carbo carbo wintering north of the Arctic circle. Bird Study 48: 59-67. https://doi.org/10.1080/00063650109461203

Johnstone I.G., Harris M.P., Wanless S., et al. 1990. The usefulness of pellets for assessing the diet of adult shags Phalacrocorax aristotelis. Bird Study 37: 5-11. https://doi.org/10.1080/00063659009477030

Lilliendahl K., Solmundsson J. 2006. Feeding ecology of sympatric European shags Phalacrocorax aristotelis and great cormorant P. carbo in Iceland. Mar. Biol. 149: 979-990. https://doi.org/10.1007/s00227-006-0259-7

Liordos V., Goutner V. 2007. Diet of the great cormorant (Phalacrocorax carbo L. 1758) at two Greek colonies. J. Biol. Res. 7: 51-57.

MAPAMA. 2017. Ministerio de Agricultura y Pesca, Alimentación y Medio Ambiente. Ecocartografía de Murcia. Comunidades marinas.

http://www.mapama.gob.es/es/costas/temas/proteccion-costa/ ecocartografias/ecocartografia-murcia.aspx

Martínez-Abraín A., Oro D., Velando A., et al. 2006. Morphometric similarities between central and peripheral populations of the European shag Phalacrocorax aristotelis. Mar. Ornithol. 34: 21-24

Mizutani H., Fukuda M., Kabaya Y., et al. 1990. Carbon isotope ratio reveals feeding behaviour of cormorants. The Auk 107: 400-403.

https://doi.org/10.2307/4087626

Molina B. 2013. El cormorán grande en España. Población repro- ductora e invernante 2012-2013. In: SEO/Birdlife Programas de seguimiento de avifauna, pp. 26-29. SEO/Birdlife. Madrid. http://www.seo.org/wp-content/uploads/2012/05/ Seguimiento_2012_OK.pdf

Morat F., Mante A., Drunat E., et al. 2014. Diet of Mediterranean European shag, Phalacrocorax aristotelis desmarestii, in a northwestern Mediterranean area: a competitor for local fisheries? Sci. Rep. Port-Cros Nat. Park 28: 113-132.

Myers R.A. 1997. Recruitment variation in fish populations assessed using meta-analysis. In: Chambers R.C., Trippel E.A. (eds). Early life history and recruitment in fish populations. Fish and Fisheries Series 21. Pp. 451-467. Chapman and Hall, London (UK) https://doi.org/10.1007/978-94-009-1439-1_16

Östman Ö., Boström M.K., Bergström U., et al. 2013. Estimating competition between wildlife and humans: a case of cormorants and coastal fisheries in the Baltic Sea. PLoS ONE 8: e83763. https://doi.org/10.1371/journal.pone.0083763

PRIMER-E. 2015. PRIMER 7 version 7.0.10. PRIMER-E, Plymouth, UK.

Privileggi N. 2003. Great Cormorants Phalacrocorax carbo sinensis wintering in Friuli Venezia Giulia, Northern Adriatic: specific and quantitative diet composition. Vogelwelt 124: 237-243.

Ridgway M.S. 2010. A review of estimates of daily energy expenditure and food intake in cormorants (Phalacrocorax spp.). J. Great Lakes Res. 36: 93-99. https://doi.org/10.1016/j.jglr.2009.10.002

Russell A.F., Wanless S., Harris M.P. 1995. Factors affecting the production of pellets by Shag Phalacrocorax aristotelis. Seabird 17: 44-49.

Ruiz J.M., Guillén E., Ramos Segura A., et al. 2015. Atlas de las praderas marinas de España. IEO/IEL/UICN, Murcia-AlicanteMálaga, $681 \mathrm{pp}$.

Steffens W. 2011. Great cormorant Phalacrocorax carbo is threatening fish populations and sustainable fishing in Europe. Am. Fish. Soc. Symp. Ser. 75: 1-12.

Taylor J.D., Dorr B.S. 2003. Double-crested cormorant impacts to commercial and natural resources. In: Fagerstone K.A., Witmer G.W. (eds) Proceedings of the 10th Wildlife Damage Management Conference, pp. 43-51.

Tuset V.M., Lombarte A. Assis C.A. 2008. Otolith atlas for the western Mediterranean, north and central eastern Atlantic. Sci. Mar. 72S1: 7-198. https://doi.org/10.3989/scimar.2008.72s17

Van Eerden M.R., Voslamber B. 1995. Mass fishing by cormorants Phalacrocorax carbo sinensis at Lake Ijsselmeer, The Netherlands: a recent and successful adaptation to a turbid environment. Ardea 83: 199-212.

Velando A., Freire J. 1999. Intercolony and seasonal differences in the breeding diet of European shags on the Galician coast (NW Spain). Mar. Ecol. Prog. Ser. 188: 225-236. https://doi.org/10.3354/meps 188225

Wanless S., Harris M.P., Morris J.A. 1991a. Foraging range and feeding locations of shags Phalacrocorax aristotelis during chick rearing. Ibis 133: 30-36. https://doi.org/10.1111/j.1474-919X.1991.tb04806.x

Wanless S., Burger A.E., Harris M.P. 1991b. Diving depths of shags Phalacrocorax aristotelis breeding on Isle of May. Ibis 133: 37-42. https://doi.org/10.1111/j.1474-919X.1991 tb04807 x

Wanless S., Grémillet D., Harris M.P. 1998. Foraging activity and performance of Shag Phalacrocorax aristotelis in relation to environmental characteristics. J. Avian Biol. 29: 49-54 https://doi.org/10.2307/3677340

Watanaki Y., Daunt F., Takahashi A., et al. 2008. Microhabitat use and prey capture of a bottom-feeding top predator, the European Shag, shown by camera loggers. Mar. Ecol. Prog. Ser. 356: 283-293. https://doi.org/10.3354/meps07266

Zamora D. 2015. III Censo de Aves Orilladas del Mar Menor 20132014. Asociación de Naturalistas del Sureste. Murcia, Spain. 56 pp.

http://www.asociacionanse.org/medio-millar-de-aves-muertasen-artes-de-pesca-en-el-mar-menor/20141130 